\title{
Anuretes grandis sp. n., a caligid copepod (Siphonostomatoida) parasitic on Diagramma pictum (Pisces) in Taiwan, with discussion of Anuretes Heller, 1865
}

\author{
Ju-shey $\mathrm{Ho}^{1}$ and Ching-Long Lin $^{2}$ \\ ${ }^{1}$ Department of Biological Sciences, California State University, Long Beach, California 90840-3702, USA; \\ ${ }^{2}$ Department of Aquaculture, National Chiayi Institute of Technology, Chiayi, 60083, Taiwan
}

Key words: fish parasite, parasitic copepod, Taiwan, Anuretes grandis, taxonomy, key to species

\begin{abstract}
A new species of caligid copepod (Siphonostomatoida), Anuretes grandis sp. n., parasitic on the painted sweetlips [Diagramma pictum (Thunberg)] in Taiwan is described. The new species is distinguished from its congeners by having: (1) free margin of cephalothorax not covering fourth pediger, (2) large genital complex longer than 2/3 of the cephalic shield, (3) no maxillary whip, (4) leg 3 with 9 setae on the terminal segment of exopod and 8 plumose setae on the terminal segment of endopod, and (5) armature of I,III on leg 4 exopod. Genus Anuretes Heller, 1865 is reviewed and redefined. Based on the new diagnosis three species (A. chelatus Prabha et Pillai, A. fedderni Price and A. parvulus Wilson) were transferred to Pseudanuretes, and two species (A. furcatus Capart and A. renalis Heegaard) were transferred to Lepeophtheirus. In addition, the following three species of caligids were transferred to Anuretes: Lepeophtheirus fallolunulus Lewis, Heniochophilus indicus Pillai, and Lepeophtheirus rotundigenitalis Prabha et Pillai. The latter is renamed Anuretes occultus nom. n. due to the homonym encountered through this transfer. "Anuretes plectorhynchi Yamaguti" reported by Prabha and Pillai (1986) is renamed Anuretes similis sp. n. and Anuretes yamagutii Prabha et Pillai is relegated to the synonym of Anuretes anomalus Pillai. A key to the 18 species of Anuretes is provided.
\end{abstract}

Although more than 200 species of marine fishes are caught for food from the waters of Taiwan, only about $15 \%$ of them have so far been examined for copepod parasites. In order to narrow this gap, we launched in 1997 a survey of commercial fishes for their copepod parasites. Up till now, we have obtained parasitic copepods from 67 of the 90 species of fishes examined. In this paper we shall report a new species of Anuretes recovered from the gills of painted sweetlips [Diagramma pictum (Thunberg)].

In their fourth part of report on the copepod parasites of the marine fishes of India, Prabha and Pillai (1986) reported seven species of Anuretes with four of them new to science. However, close examination of their report revealed that "Anuretes chelatus sp. nov." is a species of Pseudanuretes, "Anuretes yamagutii sp. nov." a misidentification for Anuretes anomalus Pillai, 1967, and "Anuretes plectorhynchi Yamaguti" a new species. Such mistakes are considered chiefly due to the ambiguity of the definition of the genus Anuretes. Thus, we shall take the opportunity of describing the first species of Anuretes from Taiwan to give a general discussion of the genus and also to provide a key to the known species.

\section{MATERIALS AND METHODS}

The fish hosts - painted sweetlips [Diagramma pictum (Thunberg)] - were purchased from the Mi-Tuo Fishing Port in Kaohsiung County of Taiwan and transferred in an icebox to National Chiayi Institute of Technology where the laboratory examination for parasites was carried out. The copepod parasites removed from the fish hosts were preserved in $70 \%$ ethanol. They were later cleared in $85 \%$ lactic acid for 1 to $2 \mathrm{~h}$ before dissection in a drop of lactic acid on a wooden slide (Humes and Gooding 1964). The removed body parts and appendages were examined under the compound microscope with a series of magnifications up to $\times 1,500$. All drawings were made with the aid of a camera lucida.

\section{RESULTS}

Anuretes grandis sp. $\mathrm{n}$.

Figs. 1-3

Female. Body (Fig. 1A) 1.72 (1.50-1.98) mm long, excluding setae on caudal rami. Cephalothoracic shield longer than wide, $0.98(0.92-1.06) \times 0.81(0.74-0.92)$ $\mathrm{mm}$, excluding marginal hyaline membrane. Fourth pediger, $0.14 \times 0.18 \mathrm{~mm}$, only partially covered by free margin of cephalothorax. Genital complex usually slightly longer than wide, $0.70(0.58-0.90) \times 0.68(0.56-$ $0.92) \mathrm{mm}$. Abdomen (Fig. 3C) much reduced, represented by reduced, bilobate anal somite located at end of genital complex. Caudal ramus (Fig. 3C) small, longer than wide, $25(24-28) \times 22(16-24) \mu \mathrm{m}$, carrying 3 short and 3 long plumose setae. Egg sac 1.15 (0.76-1.93) mm long, containing as many as 34 eggs.

Antennule (Fig. 1B) 2-segmented; proximal segment with 27 setae on anterodistal surface, distal segment with a subterminal seta on posterior margin and 11 setae 

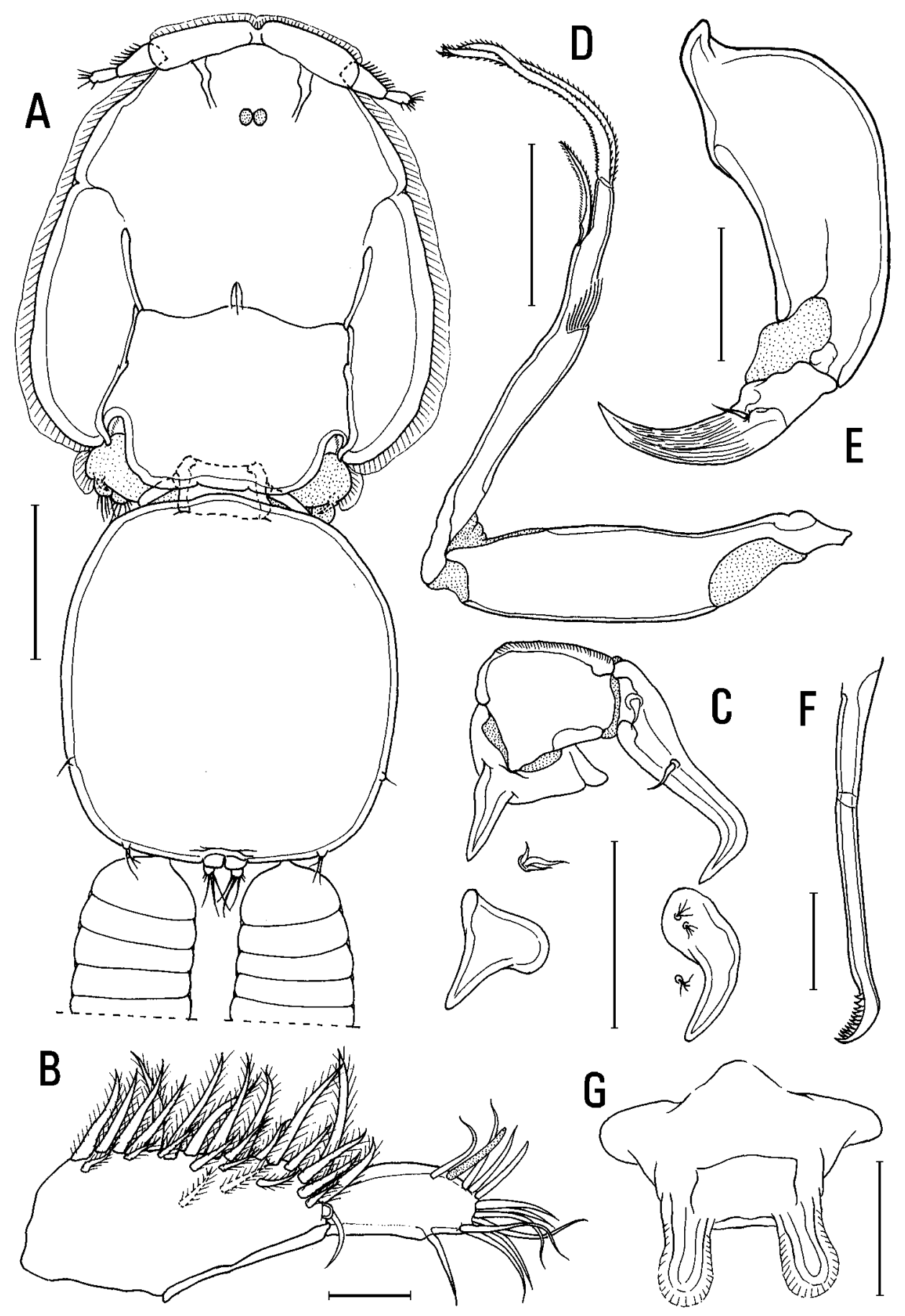

Fig. 1. Anuretes grandis sp. n., female. A - habitus, dorsal; $\mathbf{B}-$ antennule, ventral; $\mathbf{C}-$ antenna, postantennal process and maxillule, ventral; D - maxilla; $\mathbf{E}$ - maxilliped; F - mandible; $\mathbf{G}$ - sternal furca. Scale bars: A = $0.3 \mathrm{~mm} ; \mathrm{B}, \mathrm{F}=0.03 \mathrm{~mm} ; \mathrm{C}, \mathrm{E}=$ $0.1 \mathrm{~mm} ; \mathrm{D}=0.07 \mathrm{~mm} ; \mathrm{G}=0.05 \mathrm{~mm}$. 
plus 1 aesthetasc on distal margin. Antenna (Fig. 1C) 3segmented; proximal segment smallest, with sharply pointed posteromedial process; second segment rectangular and unarmed; distal segment a sharply pointed, bent claw bearing 1 seta in proximal region and another one in middle region. Postantennal process bluntly pointed claw, bearing 2 basal papillae with each bearing 4 setules. Another similar papilla located nearby on sternum.

Mandible (Fig. 1F) apparently 2-segmented; with 12 teeth on medial margin of distal blade. Maxillule (Fig. 1C) comprising short pointed process and papilla with 3 setae. Maxilla (Fig. 1D) 2-segmented; proximal segment (lacertus) large and unarmed, slender, distal segment (brachium) carrying a subterminal, hyaline membrane on outer edge and 2 unusual elements (calamus and canna) terminally. Maxillary whip (Figs. 3A,B) obtuse, bent process located posterolaterally to maxilla. Maxilliped (Fig. 1E) 3-segmented; proximal segment (corpus) largest but unarmed; middle and distal segments fused to form strong, sharply pointed claw carrying medial seta. Sternal furca (Fig. 1G) with short, obtuse, parallel tines.

Armature on rami of legs $1-4$ as follows (Roman numeral indicating spines and Arabic numeral, setae):

$\begin{array}{lll} & \begin{array}{l}\text { Exopod } \\ \text { Leg 1 }\end{array} & \begin{array}{l}\text { Endopod } \\ \text { (vestigial) }\end{array} \\ \text { Leg 2 } & \text { I-1 III, I,3 II,I,5 } & 0-1 ; 0-2 ; 6 \\ \text { Leg 3 } & \text { I-0; 9 } & 0-0 ; 6 \\ \text { Leg 4 } & \text { I-0; III } & \text { (missing) }\end{array}$

Leg 1 (Fig. 2A) protopod with long, plumose outer (anterior) seta and another small, plumose inner (posterior) seta; vestigial endopod 2-segmented and tipped with 2 setules; first segment of exopod with row of setules on posterior (inner) edge and short spiniform seta at outer (anterior) distal corner; inner 2 of 3 terminal elements on last segment of exopod (Fig. 2B) with accessory process, bipinnate setiform process originated at base of innermost terminal element. Leg 2 (Fig. 2C) coxa small, with large, plumose, inner seta on posterior edge; basis lacking outer seta; both outer and medial edges of protopod fringed with large marginal membrane. Leg 3 (Fig. 2D) protopod (apron) with large, outer marginal membrane; posterior edge with small, plumose, outer seta and large, plumose inner seta. Leg 4 (Fig. 2E) protopod with naked outer seta; pectens on exopod segments at insertion of 2 inner, terminal spines (Fig. 2F). Leg 5 (Fig. 3C) represented by a papilla bearing single, plumose seta and leg 6 (Fig. 3C) represented by a slightly larger papilla tipped with 3 plumose setae.

Ty p e host: Diagramma pictum (Thunberg).

Site of infection: gills.

Ty pe 1 o c a lity: Mi-Tuo, Kaohsiung County, Taiwan.
Prevalence and intensity:33\% (1 $\circ$ from 1 of 3 fishes) obtained on 2 April, 1999 and $50 \%$ (25 우 from 2 of 4 fishes) obtained on 14 May, 1999.

E t y $\mathrm{m}$ o 1 o g y : The species name grandis, from Latin meaning large, great, noble, magnificent, refers to the spectacular genital complex, which is nearly as large as the cephalothorax - an unusual feature for the species of Anuretes.

D e p o s i t i o n of t y p e s: Holotype (USNM 288089) and 12 paratypes (USNM 288090) have been deposited in the National Museum of Natural History, Smithsonian Institution, Washington, D.C.

Remarks. The new species from Taiwan is characteristic in having a large genital complex, which is about $71(63-85) \%$ of the size of cephalothorax. Currently, there are 20 nominal species in the genus Anuretes and only one of them, A. rotundigenitalis Hameed, bears a large genital complex like the present species. However, the new species is distinguished from A. rotundigenitalis chiefly in the armature on legs 2, 3, and 4 . In $A$. rotundigenitalis the first outer spine on the exopod of leg 2 does not reach the distal edge of the terminal segment, the distal segment of leg 3 exopod has 8 (instead of 9) setae, and the middle spine on the terminal segment of leg 4 exopod is about $1 / 2$ (instead of 4/5) the length of the inner most spine. $A$. rotundigenitalis is known from a grunt, "Diagramma crassispinum Day", collected in Cape Comorin, India (Hameed 1976).

It is noteworthy that in $A$. grandis the armature on the terminal region of the distal segment of antennule is 11 +1 aesthetasc, with one less element (either seta or aesthetasc) in comparison with most species of Caligus and Lepeophtheirus. Also, the basis of leg 2 is unusual in lacking outer seta.

\section{DISCUSSION}

\section{Genus Anuretes Heller, 1865}

In 1863 when Henrik Krøyer described Lepeophtheirus heckelii found on the spadefish, "Ephippus gigas", from Brazil and New Orleans, Louisiana, he noticed the copepod bearing a vestigial abdomen and commented that this unusual feature might warrant the creation of a new genus for L. heckelii. Krøyer's (1863) comment was adopted by Heller (1865) who proposed a new genus Anuretes to accommodate $L$. heckelii. Since the establishment of Anuretes, 19 species of caligid copepods have been described and attributed to this genus (Table 1).

Although the distinction between members of Anuretes and Lepeophtheirus was set to be the absence or great reduction of the abdomen in the species of Anuretes (Heller 1865, Wilson 1905, Heegaard 1945, Capart 1953, Lewis 1964, Pillai 1985), some members 


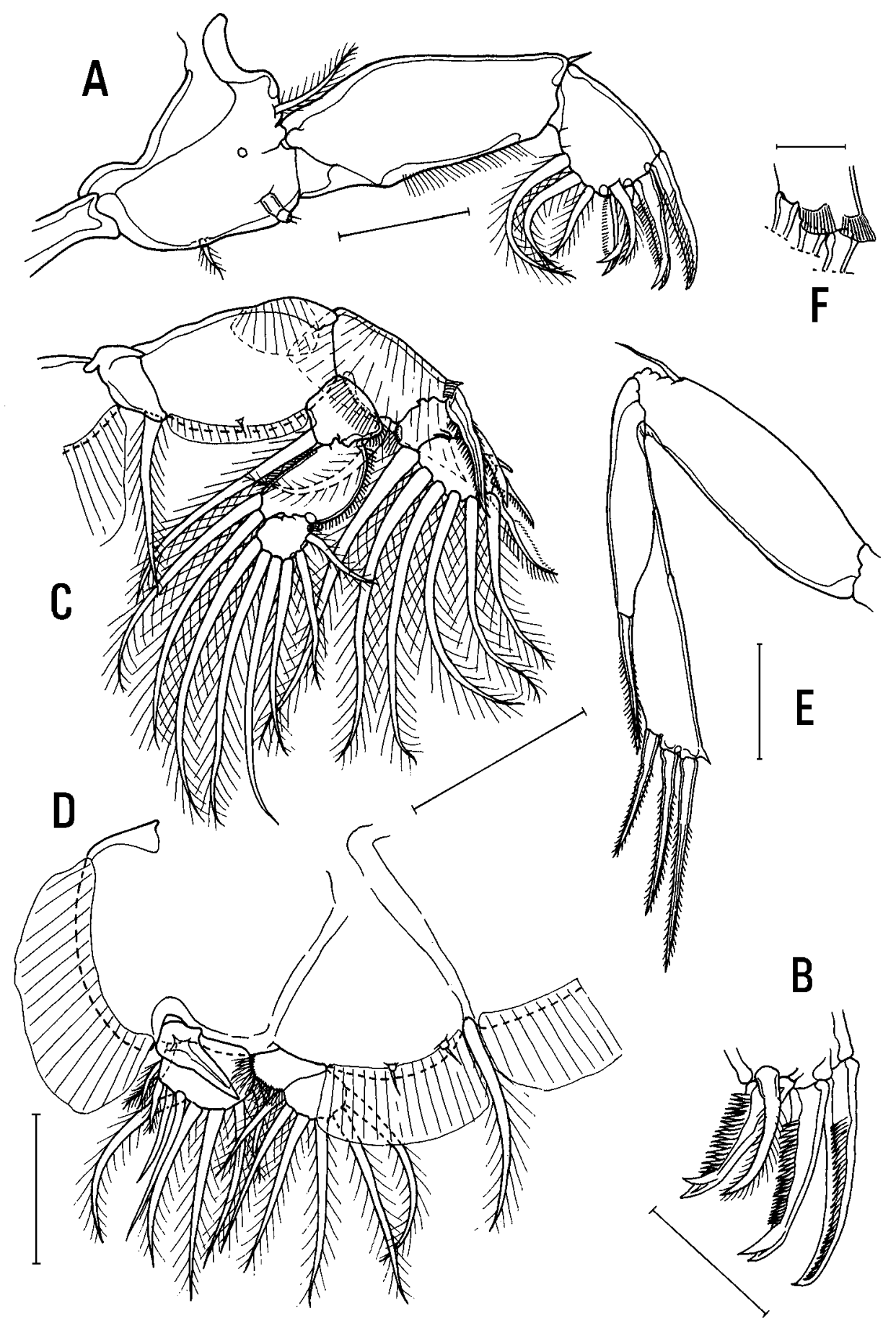

Fig. 2. Anuretes grandis sp. n., female. A - leg 1, anterior; $\mathbf{B}$ - tip of leg 1 exopod; $\mathbf{C}-\operatorname{leg} 2$, ventral (anterior); D - leg 3, ventral; $\mathbf{E}-\operatorname{leg} 4$, ventral (anterior); $\mathbf{F}$ - terminal portion of distal segment of leg 4 exopod. Scale bars: A, D = 0.07 mm; B, E = $0.05 \mathrm{~mm} ; \mathrm{C}=0.15 \mathrm{~mm} ; \mathrm{F}=0.02 \mathrm{~mm}$. 

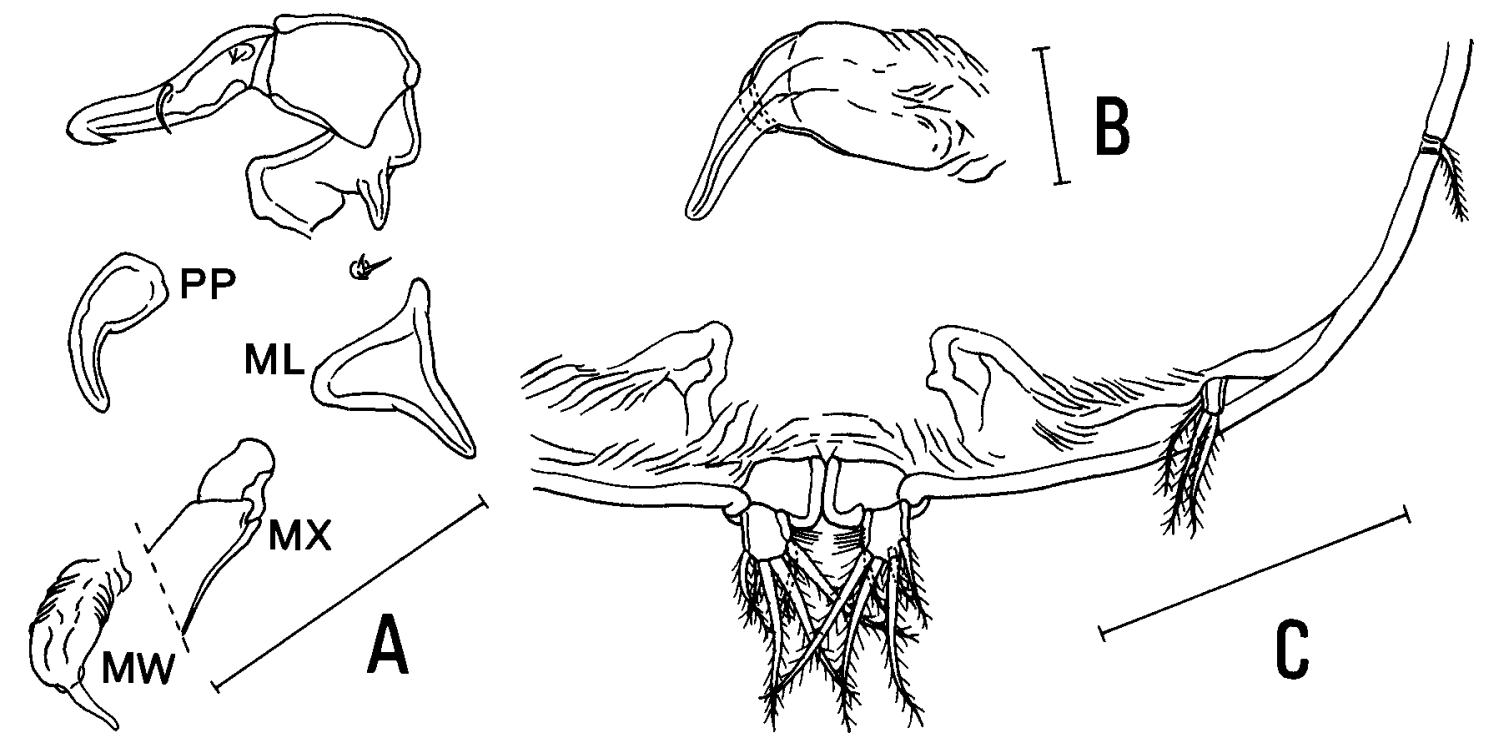

Fig. 3. Anuretes grandis sp. n., female. A - antenna, postantennal process (PP), maxillule (ML), maxillary whip (MW), basal part of maxilla (MX), ventral; B - maxillary whip; $\mathbf{C}$ - posterior portion of genital complex, ventral. Scale bars: $\mathrm{A}, \mathrm{C}=0.15 \mathrm{~mm} ; \mathrm{B}=$ $0.03 \mathrm{~mm}$.

of this genus, like $A$. furcatus, $A$. quadrilaterus, $A$. renalis, A. serratus, etc., possess a small but distinct abdomen, as in some species of Lepeophtheirus. Thus, to distinguish between these two genera by this feature alone was questioned by Shiino (1954), Pillai (1967), and Ho and Dojiri (1977). Shiino (1954) added that Anuretes could be distinguished from Lepeophtheirus by having a 2-segmented exopod on leg 4 and Pillai (1967) claimed that the occurrence of pinnate seta 4 between spines 2 and 3 on the terminal exopodal segment of leg 1 was not found in species of Lepeophtheirus. However, Ho and Dojiri (1977) opted to treat the 12 species of Anuretes known then as Lepeophtheirus until the taxonomic value of these characters can be re-evaluated.

In his unpublished work on the revision of the genera of the Caligidae, Dojiri (1983) resurrected Anuretes and distinguished it from Lepeophtheirus by a combination of the following characters:

1) Vestigial abdomen.

2) Two-segmented exopod of leg 3.

3) Absence of basal swelling or fusion of it with basal spine on exopod of leg 3 .

4) Absence of inner plumose seta of first endopodal segment of leg 3 .

5) Two-segmented exopod of leg 4.

To this combination of characters we can now add one more feature to define the scope of the genus Anuretes:

6) Pinnate seta 4 located between spines 2 and 3 on the terminal segment of exopod of leg 1 (instead of on the posterior corner or inner to the base of spine 3).
Although the last character is shared with Pseudanuretes Yamaguti, 1936, species of the latter genus are characterised in having an accessory tine on the claw of antenna and lacking postantennal process, dentiform process of maxillule, and sternal furca.

Taking into consideration the above-mentioned diagnostic combination of six characters for the genus Anuretes, it was discovered that A. furcatus Capart, 1953 and $A$. renalis Heegaard, 1945 should be transferred to Lepeophtheirus, because of the possession of a small but distinct abdomen and the 3-segmented exopod of leg 4. Since neither species was well described, no further comments can be provided. We concur with Dojiri's (1983) recommendation to transfer A. parvulus Wilson, 1913 to Pseudanuretes. Additionally, A. chelatus Prabha et Pillai, 1986 and A. fedderni Price, 1968 should also be transferred to Pseudanuretes. These two species possess an accessory tine on the terminal claw of antenna and lack the postantennal process and the dentiform process of maxillule.

While five species are suggested to be removed from the redefined Anuretes, examination of literature on 109 species of Lepeophtheirus revealed that two of them, L. fallolunulus Lewis, 1967 and L. rotundigenitalis Prabha et Pillai, 1983, should be included in the redefined Anuretes. L. fallolunulus was recovered from the gill cavity of a surgeonfish, Naso unicornis (Forsskål), in Hawaii. It was placed in Lepeophtheirus with some reservation by Lewis (1967), but based on his description, L. fallolunulus possesses all of the redefined characters of Anuretes except for the abdomen, which is reduced but not vestigial. Prabha and 
Table 1. Species of Anuretes nominated since the erection of the genus.

\begin{tabular}{|c|c|c|}
\hline Species & Host & Locality \\
\hline A. anomalus Pillai, 1967 & $\begin{array}{l}\text { Platax teira (Forsskål) } \\
\text { Diagramma pictum (Thunberg) } \\
\text { (= Spilotichthys pictus) }\end{array}$ & $\begin{array}{l}\text { Trivandrum, India } \\
\text { Heron Island, Australia }\end{array}$ \\
\hline A. branchialis Rangnekar, 1953 & $\begin{array}{l}\text { Eleutheronema tetradactylum (Shaw) } \\
\text { Heniochus acuminatus (Linnaeus) } \\
\text { Katsuwonus pelamis (Linnaeus) } \\
\text { Platax teira }\end{array}$ & $\begin{array}{l}\text { Arabian Sea } \\
\text { Shirahama, Japan } \\
\text { Bombay, India } \\
\text { Australia; Sri Lanka, Celebes; } \\
\text { Philippines }\end{array}$ \\
\hline A. brevis Pearse, 1951 & Archosargus probatocephalus (Walbaum) & Bahamas \\
\hline A. chelatus Prabha et Pillai, 1986 & Pomacanthodes imperator (Bloch) & Trivandrum, India \\
\hline A. fedderni Price, 1968 & Holacanthus ciliaris (Linnaeus) & Caribbean \\
\hline A. furcatus Capart, 1953 & Mobula rochebrunei (Vaillant) & Senegal \\
\hline A. heckelii (Krøyer, 1863) & $\begin{array}{l}\text { Caranx hippos (Linnaeus) } \\
\text { Chaetodipterus faber (Broussonet) } \\
\text { "Ephippus gigas" } \\
\text { Lobotes surinamensis (Bloch) } \\
\text { Scomberomorus maculatus (Mitchill) } \\
\text { Vomer setapinnis (Mitchill) }\end{array}$ & $\begin{array}{l}\text { Tuxpan, Mexico } \\
\text { Louisiana; Texas, Mississippi } \\
\text { Brazil } \\
\text { Louisiana } \\
\text { Texas } \\
\text { Mississippi }\end{array}$ \\
\hline A. hoi Prabha et Pillai, 1986 & $\begin{array}{l}\text { Diagramma pictum } \\
\text { (= Spilotichthys pictus) }\end{array}$ & Trivandrum, India \\
\hline A. menehune Lewis, 1964 & Naso hexacanthus (Bleeker) & Hawaii \\
\hline A. parvulus Wilson, 1913 & Angelichthys bermudensis (Jordan et Rutter) & Florida \\
\hline A perplexus Bassett-Smith 1898 & Pomacanthus arcuatus (Linnaeus) & Dry Tortugas, Florida \\
\hline A. plataxi Prabha et Pillai, 1986 & Platax teira & Trivandrum, India \\
\hline A. plectorhynchi Yamaguti, 1936 & $\begin{array}{l}\text { Diagramma pictum } \\
\text { (= Plectorhynchus pictus) }\end{array}$ & Japan \\
\hline & (= Spilotichthys pictus) & Trivandrum, India \\
\hline $\begin{array}{l}\text { A. quadrilaterus Shiino, } 1954 \\
\text { A. renalis Heegaard, } 1945\end{array}$ & $\begin{array}{l}\text { Zenopsis nebulosa (Temminck et Schlegel) } \\
\text { Diodon sp. }\end{array}$ & $\begin{array}{l}\text { Japan } \\
\text { Japan }\end{array}$ \\
\hline A. rotundigenitalis Hameed, 1976 & "Diagramma crassispinum Day" & Cape Comorin, India \\
\hline A. rotundus Prabha et Pillai, 1983 & Pomacanthodes imperator & Trivandrum, India \\
\hline A. serratus Shiino, 1954 & Naso hexacanthus & Hawaii \\
\hline & Siganus javus (Linnaeus) & Trivandrum, India \\
\hline & Xesurus scalprum (Cuvier et Valenciennes) & Wakayama, Japan \\
\hline A. shiinoii Prabha et Pillai, 1986 & Naso sp. & Trivandrum, India \\
\hline A. yamagutii Prabha et Pillai, 1986 & Plectorhinchus cinctus (Temminck et Schlegel) & Kuwait \\
\hline & $\begin{array}{l}\text { Diagramma pictum } \\
\text { (= Spilotichthys pictus })\end{array}$ & Trivandrum, India \\
\hline
\end{tabular}

Note: Information shown in this table was compiled from the following works: Capart (1953), Causey (1953, 1955, 1960), Dojiri (1983), Hameed (1976), Heegaard (1945), Ho and Sey (1996), Kabata (1965), Krøyer (1863), Lewis (1964), Pearse (1951), Pillai and Mohan (1965), Prabha and Pillai (1983, 1986), Price (1966), Rangnekar (1953), Shiino (1954), Wilson (1913, 1935), Yamaguti (1936), and Yamaguti and Yamasu (1959).

Pillai (1983) found L. rotundigenitalis in the gill cavities of a somber sweetlips, Plectorhinchus (= Gaterin) schotaf (Forsskål), from Trivandrum, India. Although the species was placed in Lepeophtheirus and claimed to be unique in bridging "the gap between several genera of Lepeophtheirinae and Anuretinae", Prabha and Pillai's (1983) description of this species fits well to the six features given above for the species of Anuretes. However, it can not be transferred to Anuretes without a name change, because the specific name is preoccupied (see Table 1). Thus, we propose to call it "Anuretes occultus nom. n." implying the fourth pediger of this species is entirely concealed underneath the free margin of the cephalothorax.
Pillai and Mohan (1965) transferred Anuretes branchialis Rangnekar, 1953 to Heniochophilus, which was established to contain one species, $H$. japonicus, by Yamaguti and Yamasu (1959). At the time of this transfer, it was also recognised by Pillai and Mohan (1965) that $H$. japonicus was conspecific with "Heinochophilus branchialis". The genus Heniochophilus remained monotypic until Pillai (1977) described $H$. indicus from a spadefish, Platax teira (Forsskål), from Kerala, India. However, after reexamination of "Heniochophilus branchialis" recovered from the spadefishes from Sri Lanka and Southeast Asia kept in ichthyological collection at National Museum of Natural History, Dojiri (1983) proposed the synonymy 
of Heniochophilus with Anuretes and returned $H$. branchialis to its original status proposed by Rangnekar (1953) and also transferred $H$. indicus to Anuretes.

Thus, in conclusion, with removal of five species (A. chelatus, A. fedderni, A. furcatus, A. parvulus, A. renalis) and addition of three species (L. fallolunulus, $L$. rotundigenitalis, and $H$. indicus), there are now 19 species of caligid copepods attributed to Anuretes, including the new species reported herein.

\section{Key to the species of the genus Anuretes}

In compiling morphological data for construction of a key to the species, it was discovered that $A$. yamagutii Prabha et Pillai, 1986 is synonymous with $A$. anomalus Pillai, 1967 and "Anuretes plectorhynchi Yamaguti" reported by Prabha and Pillai (1986) is in essence a new species. Therefore, according to Article 60 of the International Code of Zoological Nomenclature, we propose to call the latter "Anuretes similis nom. n." implying its close resemblance to A. plectorhynchi. Prabha and Pillai's (1986) description of "Anuretes plectorhynchi Yamaguti" shows that it differs from Yamaguti's (1936) A. plectorhynchi in the possession of (1) maxillary whip, (2) the fourth pediger not covered by the free margin of the cephalothorax, and (3) larger genital complex (relative to cephalothoracic shield).

As generally true for the caligid copepods, the species of Anuretes are mostly known from the female; thus, the key provided below is intended for the identification of female Anuretes. Inasmuch as $A$. brevis Pearse is known only from the male and has not been adequately described, it is excluded from the following key.

1 Armature of leg 4 exopod I,II 2

- Armature of leg 4 exopod I,IV

- Armature of leg 4 exopod I,III 3

2 Length of genital complex about $1 / 2$ that of cephalothoracic shield, 4 setae on terminal segment of leg 3 endopod A. indicus (Pillai, 1977)

- Length of genital complex about 1/4 that of cephalothoracic shield, 6 setae on terminal segment of leg 3 endopod ........ A. rotundus Prabha et Pillai, 1983

3 Dentiform process of maxillule simple ............... 4

- Dentiform process of maxillule bifid .................. 5

- Dentiform process of maxillule simple but with a hooklet A. heckelii (Krøyer, 1863)

4 Genital complex less than 1/2 length of cephalothoracic shield, 4 setae on terminal segment of leg 3 endopod .............. A. plataxi Prabha et Pillai, 1986

- Genital complex more than 1/2 length of cephalothoracic shield, 6 setae on terminal segment of leg 3 endopod A. shiinoii Prabha et Pillai, 1983

5 Inner surface of leg 3 protopod extended posteriorly into a large, heavily chitinised, blunt-tipped process; outer spine on first segment of leg 2 exopod simple ............. A. menehune Lewis, 1964

- Inner surface of leg 3 endopod without such process; outer spine on first egment of leg 2 exopod ramified

6

6 Length of genital complex greater than $1 / 2$ of cephalothoracic shield, posterior setae of leg 1 exopod simple, reduced .......... A. fallolunulus (Lewis, 1967)

- Length of genital complex shorter than $1 / 2$ of cephalothoracic shield, posterior setae of leg 1 exopod plumose, long .................. A. serratus Shiino, 1954

7 Fourth pediger completely covered by free margin of cephalothorax ..................................................... 8

- Fourth pediger not covered by free margin of cephalothorax 9

8 Length of genital complex greater than $1 / 2$ that of cephalothorax, 2 setae on terminal segment of leg 3 endopod ................. A. branchialis Rangnekar, 1953

- Length of genital complex shorter than $1 / 2$ that of cephalothorax, 6 setae on terminal segment of leg 3 endopod .............. A. plectorhynchi Yamaguti, 1936

9 Maxillary whip absent ...................................... 10

- Maxillary whip present ....................................... 11

10 Maxilliped corpus with sharp, median protuberance; 7 plumose setae on terminal segment of leg 3 exopod ............... A. perplexus Bassett-Smith, 1898

- Maxilliped corpus without median protuberance, 9 (4 simple +5 plumose) setae on terminal segment of leg 3 exopod .............. A. quadrilaterus Shiino, 1954

11 Terminal segment of leg 3 exopod with 9 elements

- Terminal segment of leg 3 exopod with 8 elements ................ 13

- Terminal segment of leg 3 exopod with 7 elements

2 Length of genital complex less than $1 / 2$ that of cephalothorax; leg 6 tipped with 4 plumose setae ... A. anomalus Pillai, 1967

- Length of genital complex greater than $1 / 2$ that of cephalothorax, leg 6 tipped with 3 plumose setae A. grandis sp. n.

13 Length of genital complex almost as long as that of cephalothorax, maxillary whip with simple, long setiform process .. A. rotundigenitalis Hameed, 1976

- Length of genital complex about $1 / 2$ that of cephalothorax; maxillary whip with a pair of short setiform processes ....................... A. similis nom. n.

14 Length of genital complex greater than that of cephalothorax; maxilliped corpus without median protrusion ................................. A. occultus nom. n.

- Length of genital complex less than $1 / 2$ that of cephalothorax; maxilliped corpus with sharply pointed, median protrusion

A. hoi Prabha et Pillai, 1986 
Acknowledgements. We would like to thank Jin-Ho Hwang for his kindness in making the necessary arrangements for us to purchase the fishes landed at the Mi-Tuo Fishing Port. Our appreciation is also due to Jia-Leng Hwang, Pin-Ju Wu and Wei-Shen Tzeng of the National Chiayi Institute of Technology for their assistance in transportation and examination of fishes. The field and laboratory works of this study was made possible through the grant (NSC 88-2313-B-
021-018) from the National Science Council of Taiwan to Ching-Long Lin and another grant (NSC 88-2811-B-0210001) from the same agent to Ju-shey Ho. Comments and suggestions made by two anonymous reviewers contributed greatly to the improvement of the quality of this paper. Completion of this study was partly funded by a grant from the Paramitas Foundation to Ju-shey Ho.

\section{REFERENCES}

CAPART A. 1953: Quelques copépodes parasites de poissons marins de la région de Dakar. Bull. Inst. Fr. Afr. Noire 15: 647-671.

CAUSEY D. 1953: Parasitic Copepoda from Grand Isle, Louisiana. Occas. Pap. Mar. Lab. Louisiana State Univ. 7: $1-18$.

CAUSEY D. 1955: Parasitic Copepoda from Gulf of Mexico fish. Occas. Pap. Mar. Lab. Louisiana State Univ. 9: 1-19.

CAUSEY D. 1960: Parasitic Copepoda from Mexican coastal fishes. Bull. Mar. Sci. Gulf Caribb. 10: 323-337.

DOJIRI M. 1983: Revision of the genera of the Caligidae (Siphonostomatoida), copepods predominantly parasitic on marine fishes. Thesis, Boston University, $721 \mathrm{pp}$.

HAMEED S.L. 1976: Description of a new species of Anuretes (Copepoda: Caligidae) from Kerala. Hydrobiologia 51: 39-42.

HEEGAARD P. 1945: Some parasitic copepods from fishes in the Uppsala University collections. Ark. Zool. 35A: 1-27.

HELLER C. 1865: Crustaceen. Reise der Österreichischen Fregatte Novara um die Erde in den Jahren 1857, 1858, 1859. Zool. Theil, 2: 1-280.

HO J.-S., DOJIRI M. 1977: Parasitic copepods on the fishes of the Great Barrier Reef, Australia. Part II. Caligoida: Dissonus, Lepeophtheirus, and Dentigryps. Publ. Seto Mar. Biol. Lab. 24: 77-97.

HO J.-S., SEY O. 1996: Parasitic Copepoda of marine fishes from Kuwait: a preliminary report. Kuwait J. Sci. Eng. 23: 61-69.

HUMES A.G., GOODING R.R. 1964: A method for studying the external anatomy of copepods. Crustaceana 6: 238240.

KABATA Z. 1965: Copepoda parasitic on Australian fishes. III. Genera Dentigryps, Heniochophilus, and Pseudanuretes (Caligidae). Ann. Mag. Nat. Hist., ser. 13, 8: 1931.

KRØYER H. 1863: Bidrag til Kundskab om Snyltekrebsene. Copenhagen, $352 \mathrm{pp}$.

LEWIS A.G. 1964: Caligoid copepods (Crustacea) of the Hawaiian Islands: parasitic on fishes of the family Acanthuridae. Proc. U. S. Nat. Mus. 115 (3482): 137-244.

LEWIS A.G. 1967: Copepod crustaceans parasitic on teleost fishes of the Hawaiian Islands. Proc. U. S. Nat. Mus. 121 (3574): 1-204.

PEARSE A.S. 1951: Parasitic crustacea from Bimini, Bahamas. Proc. U. S. Nat. Mus. 101 (3280): 341-372.
PILLAI N.K. 1967: Description of a new species of Anuretes (Copepoda: Caligidae) and comments on the validity of a few caligid genera. Zool. Anz. 178: 358-367.

PILLAI N.K. 1969: Notes on some copepod parasites in the collection of the British Museum (N.H.), London. J. Mar. Biol. Assoc. India 11: 149-174.

PILLAI N.K. 1977: Copepods parasitic on Platax teira in Indian waters. Aquat. Biol. 2: 53-60.

PILLAI N.K. 1985: Fauna of India: Parasitic Copepods of Marine Fishes. Technical and General Press, Culcutta, 900 pp.

PILLAI N.K., MOHAN R.S. 1965: Observations on the genus Heniochophilus (Copepoda) with a redescription of the type species. J. Mar. Biol. Assoc. India 7: 270-276.

PRABHA C., PILLAI N.K. 1983: Additions to the copepods parasitic on the marine fishes of India. 1. On twelve species of caligids. Rec. Zool. Surv. India Occas. Pap. 46: $1-46$.

PRABHA C., PILLAI N.K. 1986: Additions to the copepods parasitic on the marine fishes of India. 4. On twenty-six species of caligids. Rec. Zool. Surv. India Occas. Pap. 79: $1-139$.

PRICE C.E. 1966: A new species of parasitic copepod from the Caribbean. Caribb. J. Sci. 6:119-122.

RANGNEKAR M.P. 1953: Anuretes branchialis sp. nov. a copepod parasitic on the fish Thunnus pelamys. J. Zool. Soc. India 5: 239-242.

SHIINO S.M. 1954: Copepods parasitic on Japanese fishes. 3. On two new species of the genus Anuretes. Rep. Fac. Fish. Prefec. Univ. Mie 1: 260-272.

WILSON C.B. 1905: North American parasitic copepods belonging to the family Caligidae. Part 1 . The Caliginae. Proc. U.S. Nat. Mus. 8, (1404): 479-672.

WILSON C.B. 1913: Crustacean parasites of West Indian fishes and land crabs, with descriptions of new genera and species. Proc. U. S. Nat. Mus. 44 (1950): 189-277.

WILSON C.B. 1935: Parasitic copepods from Dry Tortugas. Pap. Tortugas Lab. 29: 329-347.

YAMAGUTI S. 1936: Parasitic copepods from fishes of Japan. Part 2. Caligoida, I. By author, Japan, 22 pp. +7 plts.

YAMAGUTI S., YAMASU T. 1959: Parasitic copepods from fishes of Japan with description of 26 new species and remarks on two known species. Biol. J. Okayama Univ. 5: 89-165. 